\title{
O império do divino: uma proposta de glossário dos personagens que compõem a Festa do Divino Espírito Santo em Marabá - PA
}

\author{
The empire of the divine: a glossary \\ proposal of the characters that make up \\ the Festa do Divino Espírito Santo in \\ Marabá - PA
}

Gabriela Pereira da Silva ${ }^{1}$ http://orcid.org/0000-0002-3746-0516

Eliane Pereira Machado Soares ${ }^{2}$ https://orcid.org/0000-0002-2371-3236

Resumo: Este artigo resulta da pesquisa sobre a Festa do Divino Espirito Santo, na cidade de Marabá, Estado do Pará. Tem como objetivo elaborar um glossário com termos que nomeiam os personagens que constituem as festividades realizadas nos bairros: Santa Rosa e Santa Rita. Identificamos e registramos itens lexicais que caracterizam as figuras que conduzem todo o ritual. Os estudos sobre o léxico, de uma atividade cultural que ocorre em comunidades que falam a mesma língua e ocupam espaços diferentes indicaram a influência de fatores de natureza sociocultural e histórica. Nessa perspectiva, inserimos a Socioterminologia, uma disciplina que desenvolve métodos de análise para os termos e para a descrição dos eventos da língua considerando as características de variação no contexto social, histórico e linguístico, em que ocorrem as manifestações da fala e da escrita, como defende Enilde Faulstich.

Palavras-chave: Léxico; Vocabulário; Festa do Divino.

Abstract:

This article is the result of a research on the Divine Holy Spirit Feast, in Marabá city, State of Pará. Our purpose is to elaborate a glossary with terms that name the festivities characters in Santa Rosa and Santa Rita neighborhoods. We identify and record lexical items that characterize the figures that lead the whole ritual. The studies on the lexicon of a cultural activity that occurs in communities that speak the same language and occupy different spaces indicated

\footnotetext{
${ }^{1}$ Universidade Federal do Sul e Sudeste do Pará. E-mails: gabiescola2018@gmail.com / gabinina_silva@hotmail.com

${ }^{2}$ Universidade Federal do Sul e Sudeste do Pará. E-mail: eliane@unifesspa.edu.br
} 
the sociocultural and historical factors influence. In this perspective, we inserted Socioterminology, a theory that develops methods of analysis for the term and for the description of the events of the language considering the characteristics of variation in the social, historical and linguistic context, in which the manifestations of speech and writing occur, as defends Enilde Faulstich.

Keywords: Lexicon, Vocabulary, Feast of the Divine.

\section{Introdução}

Traço dos mais característicos do povo brasileiro, a cultura popular, também conhecida como cultura da rua ou simplesmente riso, tem no nosso país um dos campos mais férteis para se mixar, reinventar. Deriva de um rico processo só justificado pela diversidade étnica de nossa população.

As múltiplas facetas culturais da camada mais simples e numerosa da nossa gente proporcionam um verdadeiro espetáculo da espontaneidade, resultado do casamento de costumes antigos (alguns com mais de um século) com outros que vão se agregando àqueles com o passar do tempo. Caso de variações como a do Divino na Pedra que é uma vertente da Festa do Divino Espírito Santo, nossa pesquisa se debruçou sobre esta última.

As manifestações que nascem no seio do povo simples, como pescadores, trabalhadores braçais, artesãos, costureiras, parteiras, vendedoras de comida, vaqueiros e daí por diante, harmonizam-se numa complexa fábrica de emoções, capaz de seduzir o mais cético dos observadores.

Não é difícil imaginar como é possível a coexistência da cultura de rua com o avanço tecnológico, apesar da sociedade moderna e sua geração do Facebook, twitter, e-mail e tantas outras ferramentas, que reduzem significativamente o contato direto e pessoal, tão necessário para a existência de tais manifestações.

Nosso intuito com o trabalho que se apresenta é o de mostrar os fatos culturais e religiosos que se cruzam, apresentando com reflexões os diversos atores que nos ajudam a explicar o cotidiano festivo do brasileiro.

Trabalhamos a memória através das narrativas, a linguagem própria dos personagens da festividade, como a representação da estrutura organizacional da festa, da comunidade, da fala e identidade cultural dos mesmos. Assim, a festa é o espaço em que os discursos de ribeirinhos, professores, jornalistas, donas de casa e jovens se cruzam remontando subjetivamente as expressões socioculturais, individuais e coletivas dos grupos em estudo.

O trabalho foi realizado a partir da coleta audiovisual de entrevistas com as principais lideranças, das entidades do Divino Espírito Santo, localizado nos bairros Santa Rosa e Santa Rita, situados no núcleo Marabá Pioneira, em Marabá. Atemo-nos a esses dois instrumentos para a realização desse artigo, devido à construção do gênero que não permite aprofundamento e também porque nesse período essas duas divindades estão realizando os festejos, o que tornou possível realizar as entrevistas no momento da organização e realização das celebrações.

A discussão que se apresenta neste texto relaciona o campo da Lexicologia, os princípios da Terminologia e mais especificamente da Socioterminologia, na tentativa de produzir um glossário incorporando termos utilizados pelos participantes da Festa do Divino Espírito Santo de divindades distintas em Marabá.

O processo de escolha do tema, dessa maneira, pautou-se nas experiências das festividades no município que servem de estímulo para a análise historiográfica e terminológica das narrativas dos sujeitos envolvidos na Festa do Divino Espírito Santo, nesses bairros. Entretanto, atualmente em Marabá, somam-se 21 divindades, de acordo com o presidente da Associação do Divino Espirito Santo, Vitor Haor.

No município notamos o desparecimento dessas práticas, a redução dos números de participantes e a diminuição do período dos festejos, ocasionando o apagamento de uma tradição tão importante para a cultura 
local e que faz parte da história da cidade. Isso ocorre devido a diversos fatores, como o alcoolismo, que afeta alguns foliões que participam da festividade, além da crise financeira, falta de políticas públicas eficientes de incentivo, inclusive financeiros, e a intolerância religiosa por parte de pessoas que participam de outras denominações religiosas, como fica evidenciado nas falas das informantes:

\begin{abstract}
Aí a maioria hoje, caiu por isso, o que fez cair foi a bebida, a falta de respeito né? Foi isso que fez cair. [...] Eu concordo que sim, se não levar a sério eu acho que vai ficar pouquíssimo, porque era assim, hoje vai sair uma Divindade, o giro que eles fala né?! Nossa a pessoa já ficava na porta esperando aquela bandeira entrar em sua casa, porque era uma tradição você receber a Divindade na sua casa, pegar naquela bandeira, naquela coroa, hoje o pessoal bate a porta minha filha, bate a porta, bate a porta. Daqui eles vão embora não tem uma casa que eles recebe, aí vai pra Santa Rita que lá tem uma menina que festeja também, é aí que ele vai ser recebido, tanto que, e antes não, cada casa queria receber, aí já tem muito evangélico também que não aceita também. (Dona Maria Lucia, Bairro Santa Rosa)
\end{abstract}

Verificamos ainda, que não há registro do vocabulário usado por esses grupos e acreditamos ser importante fazê-lo para que haja documentação dessa celebração.

Dessa maneira a proposta desse artigo consiste em produzir um glossário sobre os termos que designam os personagens que constituem a festa do Divino em Marabá, utilizados pelos foliões residentes nos Bairros Santa Rosa e Santa Rita, a partir das narrativas experienciais dos entrevistados, em relação ao seu envolvimento nas festas do Império do Divino.

Acreditamos que a Festa possui uma terminologia própria, constituída seja por termos criados para fins específicos, como a descrição e realização da festa, seja por itens do léxico geral da língua portuguesa, que, no âmbito da manifestação, assumem novos significados, equivalentes ou complementares. Nosso trabalho se sustenta na possibilidade de sistematizar esses termos em forma de glossário que facilitará o estudo de outros pesquisadores e estudantes da cultura popular.

Optamos por estruturar os termos por ordem alfabética, além disso estabelecemos campos de maneira a fornecer dados sobre a categoria dos termos (substantivos, adjetivos, verbos, sintagmas), sobre o significado do termo naquela língua de especialidade e sobre o significado que ele assume em dado contexto, ou seja, o conhecimento pragmático. Para a elaboração do glossário, utilizamos a ferramenta computacional Lexique Pro, que permite construir dicionários digitais em sua plataforma.

\title{
Considerações iniciais sobre o estudo de lexicologia e terminologia
}

Discorrer sobre Lexicologia e Terminologia requer elucidação inicial do conceito de léxico, comumente confundido com vocábulo, para então estabelecer a definição de termo e, paralelamente o de língua especializada.

Segundo o dicionário Houaiss (2015), entende-se por léxico "... o repertório total de palavras existentes numa determinada língua...". Em Câmara Jr. o léxico é visto como sinônimo de vocabulário, o conjunto de vocábulos de que dispõe uma dada língua, além de um sistema aberto com um número indefinido de elementos, por isso é no léxico que se verificam amplamente as mudanças ocorridas na língua.

A discussão que se apresenta neste trabalho relaciona o campo mais vasto da Lexicologia, os princípios da Terminologia e, mais especificamente, pretendemos lançar mão da Socioterminologia defendida pela autora Enilde Faulstich, como disciplina que desenvolve métodos de análise para o termo e para a descrição dos eventos da língua, considerando as características de variação no contexto social, histórico e linguístico em que ocorrem 
as manifestações da fala e da escrita.

A Lexicologia, uma das áreas estudadas é definida geralmente como a ciência que estuda o léxico, este como conjunto de palavras de uma dada língua e que pode compreender vários domínios de estudos linguísticos, entre eles a etimologia, a morfologia, a sintaxe e a semântica com a qual mantém uma relação mais próxima.

Por outro lado, apreciamos os estudos da Terminologia que, para Cabré (1993), é, antes de tudo, um estudo dos sistemas conceituais que delineiam cada matéria especializada da língua, na tentativa de produzir um glossário incorporando termos de divindades distintas, utilizados pelos participantes da Festa do Divino Espírito Santo em Marabá, visando definir conceitos gerais aos termos que designam os personagens que integram a festividades, relatadas durante as entrevistas, levando em consideração o contexto de uso.

Realizar estudos sobre o léxico de uma atividade cultural como o Divino Espirito Santo, que ocorre em comunidades que falam a mesma língua, mas que ocupam espaços diferentes, com pessoas distintas que a constituem, pode revelar a influência de fatores de natureza geográfica, sociocultural e histórica sobre as escolhas lexicais.

Nessa linha de raciocínio, inserimos a Socioterminologia, uma disciplina que desenvolve métodos de análise para o termo e para a descrição dos eventos da língua considerando as características de variação no contexto social, histórico e linguístico, em que ocorrem as manifestações da fala e da escrita.

No dicionário eletrônico de Mario Barité, professor de uma universidade no Uruguai, aparece o termo traduzido e assim definido:

Socioterminologia. Rama de la Terminologia que se ocupa del análisis de los términos (surgimento, formación, consolidación e interrelaciones), considerandólos desde uma perspectiva linguística em la interacción social. 2. Disciplina eminentemente práctica del trabajo terminológico, que se fundamenta en el análisis de las condiciones sociales y linguísticas de circulación de los términos (BARITÉ, 2000).

No Brasil, o aspecto maior, que é o da circulação dos termos, já havia sido apresentado por Enilde Faulstich, da Universidade de Brasília, quando afirma: "socioterminologia como prática de trabalho terminológico, fundamenta-se na análise das condições de circulação do termo no funcionamento da linguagem. (FAULSTICH, 1999, p. 95).

Assim, a Socioterminologia ocupa-se "da variação terminológica tendo como princípio de sua pesquisa o registro e análise de variantes terminológicas, levando em consideração os contextos sociais, situacionais, espaciais e linguísticos em que os termos circulam" (VASCONCELOS, 2003, p. 144).

Faulstich (2001) defende que a teoria da variação em terminologia deve levar em consideração os diferentes valores que pode assumir um termo, segundo a função e o contexto em que ele se encontra. Podem ser avaliados a partir das perspectivas diacrônica e sincrônica, e dividir-se em dois grandes grupos: a variação linguística (variante terminológica morfossintática, lexical, gráfica) e a variação de registro (variante terminológica geográfica, de discurso e temporal).

Destarte, o que realizamos foi o registro dos discursos proferidos durante as entrevistas para evidenciar os termos que nomeiam os personagens do Festejo do Divino e os colocamos no glossário apresentado na seção 4 deste artigo.

\section{Os caminhos do Divino Espírito Santo: uma perspectiva histórica}


Martha Abreu (1999) situa historicamente a festa do Divino Espírito Santo, no Brasil, especialmente na cidade do Rio de Janeiro, caracterizando-a como uma rica tradição religiosa e cultural, que comemora a ascensão do Espírito Santo, quarenta dias após a Páscoa.

O ritual, segundo a autora, tem como figuras principais os membros da realeza, como o Imperador, Imperatriz, Rei e Rainha, além da imagem da pomba que representa o Divino Espírito Santo, a terceira pessoa da trindade.

Segundo Câmara Cascudo, em seu Dicionário do folclore brasileiro, de 1954, a festa tem sua origem atribuída a Santa Isabel, rainha de Portugal, casada com o rei D. Diniz de Portugal, ainda no século XIV, muito antes da Reforma católica, que mandou construir uma Igreja do Espírito Santo na vila de Alenquer e logo a festa se tornou uma das mais populares, por se caracterizar especialmente pela entrega de esmolas aos mais necessitados os "vodos".

\begin{abstract}
Desde os primeiros tempos, no domingo de manhã, um sacerdote comandava a solenidade de coroação do imperador simbólico e de dois reis que o assistiam; a rainha Isabel convocava toda a nobreza a participar. À tarde, saía o imperador, da igreja do Espirito Santo, com muitas festas e trombetas; uma multidão acompanhava até a igreja de São Francisco, onde os nobres dançavam com duas donzelas "honestíssimas" e de novo havia coroação. Nos dois domingos seguintes continuava a festa, sendo que, no último, se estendia muito pela noite adentro. (ABREU, 1999, p. 39)
\end{abstract}

Trazida pela Coroa Portuguesa, sediada no Brasil, a festa do Divino, ou melhor, os registros na capital do Império, datam da primeira metade do século XIX, e já davam indícios claros da aproximação entre as festividades e os traços que definiam a identidade nacional e a civilização brasileira. "Os registros sobre as festas do Divino Espirito Santo no século XIX situam-se exatamente na encruzilhada entre o resgate dos costumes populares e sua relação com uma determinada visão sobre o "povo" e a "nacionalidade". (ABREU, 1999, p. 131)

De acordo com relatos de historiadores memorialistas, como Vivaldo Coaracy, citado por Abreu, durante o período colonial todas as camadas da sociedade se reuniam na celebração, desde o vice-rei até negros (Abreu não sabe ao certo se eram livres ou ainda escravos) que exerciam, além da profissão de barbeiros, toda sorte de atividades braçais. Esses indivíduos de diferentes classes sociais nos dias de celebração ocupavam papeis e espaços comuns dentro da festa, essa mistura quebrava a monotonia do cotidiano da cidade do Rio de Janeiro.

As celebrações iniciam geralmente em maio, mas os preparativos bem antes. No sábado de Aleluia, o mastro simbólico era erguido com a imagem da pombinha, para marcar o tempo do Divino, mais tarde esse mesmo mastro serviria de pau-de-sebo nas brincadeiras. Era e ainda é comum o hábito de pedir esmolas pelos devotos, para reunir recursos para as irmandades que financiam as festas e os irmãos mais carentes. A festa durava meses, com diversas celebrações entre elas as comemorações dos santos juninos, como São João e São Pedro.

É importante destacar, que nenhuma etnia se identificava tanto com a pombinha quanto os homens e mulheres negras; a autora nos aponta que boa parte dos escravos veio da África Central, Angola e Congo, e traziam consigo suas crenças, valores e ideias e, apesar de pertencerem a diferentes nações, compartilharam no Brasil, em especial na capital, uma série de traços religiosos e culturais, chegando a construir uma "identidade bantu".

A pomba do Divino pode ter sido identificada por esses grupos, em sentido e forma com o pássaro de prata das regiões de onde vieram, ligado a iluminação, ao limite entre o dia e a noite, a vida e a morte. Além, principalmente da ideia de que na Páscoa, os donos libertavam alguns de seus escravos, animais, doavam roupas e comidas, como nos tempos de Cristo.

Assim, a festa seguia acompanhada de cantigas, leilões, celebrações, danças e liberdade. O Divino era 
apresentado como amigo dos pobres e consolador após a morte, uma celebração em que o povo é empunhado na figura do Imperador, de poder, gloria e autoridade, carnavalizando a realeza e reconfigurando a estrutura social.

Para os escritores memorialistas, segundo Abreu (1999), a festa do Divino era um importante "folguedo popular", uma valiosa manifestação popular que necessitava ser registrada e recuperada, pois no final do século XIX e início do XX, ela se tornou apenas uma comemoração de paróquia.

As manifestações saíram da esfera popular para o controle da Igreja Católica, que também passou por transformações significativas e perdeu seu espaço ao lado do Estado, mesmo sendo o catolicismo uma religião consolidada como nacional e oficial pela Constituição de 1824.

A escritora nos aponta ainda que em 1830 já eram perceptíveis as mudanças nas festas de rua, como os batuques e as comemorações negras que passaram a ser cerceadas, a pompa e o número de procissões diminuíram consideravelmente e a do Divino não fugiu a essa nova ordem.

\begin{abstract}
De uma forma geral, grande parte das elites políticas e intelectuais, dentro do espirito liberal e secular do período, assumiu uma posição anticlerical e, progressivamente, associou o catolicismo ao obscurantismo e ao atraso, algumas autoridades policiais e municipais condenaram as festas nas ruas, com duas barracas e diversões, por serem locais de jogo e vagabundagem; os médicos, por sua vez, passaram as festividades religiosas como barbaras, perigosas, vulgares e ameaçadoras da "família higiênica", e, finalmente, a liderança religiosa começou a se preocupar mais sistematicamente com as ditas deficiências do catolicismo brasileiro, marcadas pelo despreparo do clero e pela prática religiosa distante dos cânones oficiais. (ABREU, 1999, p. 37)
\end{abstract}

Mesmo sofrendo diversas modificações e restrições, a Festa do Divino Espírito Santo, no entanto, atravessou séculos resistindo, seus devotos sempre encontraram uma forma de reatualizar e prosseguir com essa tão rica e importante manifestação popular que hoje ganhou novo corpo e se espalhou pelas entranhas do Brasil, chegando há mais de um século em Marabá, no sudeste do Pará, da qual trataremos a seguir.

\title{
2.1 O Divino Espirito Santo em Marabá: remontando a Trajetória do Divino
}

De acordo com relatos históricos, a cidade foi fundada pelos maranhenses Carlos Gomes Leitão e Francisco Coelho. O primeiro instalou na região um Burgo Agrícola em 05 de agosto de 1895, e o segundo instalou-se no Pontal, que mais tarde se tornaria Vila Marabá, oficialmente em 07 de junho de 1898, com seu comércio, onde hoje localiza-se o bairro Francisco Coelho, o mais antigo da cidade.

Em 05 de abril de 1913, foi realizada a cerimônia de instalação do município de Marabá, ocasião em que se deu início a Era dos Intendentes, que durou 17 anos, tendo como primeiro intendente o presidente da comissão administrativa o Tenente-Coronel Antônio da Rocha Maia. Somente em 27 de outubro de 1923, contudo, é que recebeu o título de cidade, através da lei 2.207.

O município, hoje centenário, possui cerca de 275,86 mil habitantes (segundo dados do IBGE, 2018). Sua população é formada pela miscigenação de povos oriundos de vários estados como Maranhão, Ceará, Minas Gerais, e até por estrangeiros, como os libaneses, que iniciaram na região as atividades comerciais.

A cidade é considerada a quinta maior colônia de descendentes árabes do Brasil, tanto brasileiros como estrangeiros se mudaram para o Pará no século XIX, atraídos pela exploração do caucho e da castanha-do-Pará, constituíram famílias e criaram os primeiros comércios da cidade.

Rica por sua diversidade cultural e linguística, a cidade é um ótimo campo de pesquisa que precisa ser 
estudada. Assim, escolhemos trabalhar a Festa do Divino Espírito Santo na fala dos foliões que foram influenciados pela cultura local, a partir dos relatos desses indivíduos, que revelam suas ideologias e maneira de celebração.

A pesquisa de mestrado de Silva (2018) identificou que, na cidade de Marabá, há atualmente vinte e um grupos que festejam a divindade e são resultados dessa hibridização de culturas, crenças e ideologias de diversos lugares do país, que diante do novo ambiente ressignificaram suas práticas para sobreviverem e prosseguirem cultuando a Terceira Pessoa da Trindade. Então, notaremos que o Divino de Marabá já é uma dialogia com outras culturas, crenças e modos de celebrar.

De acordo com as informações coletadas através das dez entrevistas já realizadas para a dissertação, as celebrações iniciam-se no mês de maio com a procissão no bairro Liberdade, organizada pelo Divino dos Inocentes, uma variação do Divino Espirito Santo, que é herança de Juazeiro do Norte, Padre Cicero, é o único no município que tem a bandeira azul e que tem toda a festa direcionada e protagonizada por crianças.

Nesse encontro várias divindades participam para dar início ao tempo do Divino que culminará com a "barqueata" de encerramento das festividades com a presença das vinte e uma divindades que saem do bairro Amapá e vão até a Igreja do Divino no bairro Santa Rosa, no mês de agosto.

Apesar desse vasto banco de informações, para este artigo, no entanto, escolhemos apenas dois grupos, localizados no bairro Santa Rosa e Santa Rita, que figuram entre as mais antigas festividades do município. A primeira imagem tem mais de 150 anos, segundo a entrevista da senhora Maria Lucia Gomes Dias (informante 1) e veio com os pais de seu marido de Belo Horizonte, Minas Gerais, onde a família já celebrava a divindade.

Vale destacar que a imagem da pomba, que é o mais importante símbolo da festa e é transmitida dentro da mesma família, de pai para filho, mãe para filha, tia para sobrinho, ou de sogra para cunhada ou cunhado, nora, genro etc.

A Divindade do bairro Santa Rita, conforme nos contou a senhora Marinalva Silva da Paz (informante 2) tem 110 anos de celebração e é originária da Vila Ponta de Pedra, pertencente ao munícipio de São João do Araguaia e foi confiada a ela por sua mãe, que já havia recebido a responsabilidade de seu avô e assim sucessivamente; ela acredita que a família é oriunda do Maranhão, mas não sabe exatamente de onde vieram seus antepassados.

A maioria das manifestações realizam suas festas em três dias da semana, sempre sexta, sábado e domingo, e se inicia com a reza de abertura que é organizada pelos donos da divindade e dirigida pelo $1^{\circ}$ Folião ${ }^{3}$ que conduz a reza seguindo o terço católico. Durante o dia de sábado, acontece um ritual muito importante: o levantamento do mastro com a bandeira do Divino, dentre as 20 bandeiras vermelhas, exceto a dos Inocentes que veio de Juazeiro do Norte, como já mencionamos, que é azul e branca.

Esse momento serve para marcar a casa em que a Pomba está presente, anuncia que ali terá celebração nos próximos dias, à noite os foliões realizam mais uma reza e os promesseiros, que vêm muitas vezes de longe para pagar suas promessas, cumprem o intento prometido, que vai desde passar toda a celebração dos três dias de joelhos, até ficar em baixo do altar da Pombinha em todas as cerimonias.

Em algumas celebrações, como no bairro Independência, após a reza os foliões, promesseiros e visitantes iniciam as danças como a sússuia (também conhecida como suça), misturados com as bebidas e comilanças típicas da manifestação.

\footnotetext{
${ }^{3}$ Foliões s.m. Pessoas responsáveis pela organização da reza, da festa e das cantorias no domingo de enecerramento do festejo, ponto alto da celebração, em que ocorre a mesa do Imperador. Nas celebrações há divisão de tarefas entre o $1^{\circ}, 2^{\circ}$ e $3^{\circ}$ folião, figuras importantes dentro da irmandade. (SILVA 2018)
} 
No domingo, é o auge da festa, a partir do meio dia tem início a mesa do Imperador, momento em que ocorre a coroação do Imperador e da Imperatriz, que são geralmente rapazes e moças de até 17 anos. Esse momento da celebração é muito rico em detalhes e rituais, os doze foliões representando os doze apóstolos ficam em volta da mesa que está servida dos mais deliciosos quitutes preparados por voluntários, que dão voltas ao redor da mesa cantando e recitando as ladainhas.

O Imperador, personagem principal dessa festa, depois de todo o ritual, autoriza que todos da mesa comam. É importante frisar que há um canto para cada momento, desde a abertura das festividades até os rituais da mesa do Imperador, sempre acompanhado de violão, pandeiro e tambores diversos. Os demais comem depois fora da mesa, pois esta é um símbolo sagrado, representa a última ceia de Jesus com seus discípulos e só estes podem rodeá-la.

Na segunda feira, ocorre o derrubamento do mastro, sempre acompanhado de cantigas e ladainhas, há a despedida do Divino, dos foliões, promesseiros, donos das divindades intitulados de Imperador velho ou Imperadera velha. É um envolvente ritual de muita emoção e expectativa para o ano seguinte, nesse momento os visitantes de outras localidades e estados vão embora com a saudade e o desejo de retornar em breve.

Destacamos, entretanto, que na festa organizada pela informante 1, Maria Lúcia, no bairro Santa Rosa, assim como na celebração realizada na Vila do Espirito Santo, que se localiza no interior do município de Marabá, a manifestação dura dez dias, nove noites de novenas e o domingo da Mesa do Imperador.

No caso da festa do bairro Santa Rosa, que é onde nos deteremos, nos primeiros cinco dias são realizadas novenas dirigidas pelos noitários ${ }^{4}$, iniciando com as crianças e terminando com os mais velhos. Nos últimos quatro dias, a festa segue o mesmo ritual descrito anteriormente, diferenciando-se apenas pelo fato de ocorrer um pequeno giro pelas ruas, procissão que busca o Imperador e Imperatriz em suas casas para serem levados até a Igrejinha do Divino, que é mantida pela família de Dona Lúcia.

1 Não sabe, agora que não estão fazendo muito, mas, por exemplo, ele, o noitário, era responsável por tudo, pela limpeza do salão, decoração do altar sabe? Cada dia, aí lanche fica a critério dele, fica a critério deles, né, servir um lanche após a celebração do terço, começa com as crianças, na segunda a noite (Informante 1).

\section{Contextualização e metodologia da pesquisa}

A pesquisa foi realizada no município de Marabá, haja vista que é um espaço de atravessamentos culturais, um local de fronteiras, formado por imigrantes de toda parte do país.

Realizamos duas entrevistas com donas das divindades mais antigas do município de Marabá, no sudeste do Pará, a pertencente à senhora Maria Lucia Gomes Dias (informante 1) e à da senhora Marinalva Silva da Paz (informante 2). A divindade da Informante 1, segundo a entrevistada conta com 150 anos de celebração, está localizada no Bairro Santa Rosa; a da informante 2, segundo a entrevistada, a imagem tem um século de existência, é celebrada atualmente no bairro Santa Rita, ambas no núcleo da Velha Marabá.

Optamos por usar os nomes reais das informantes e não fictícios, uma vez que temos a autorização assinada pelas informantes. Elas se identificam como donas das divindades e solicitaram que as nomeássemos.

\footnotetext{
${ }^{4}$ Noitários S.m. Pessoas responsaveis pela organização das novenas, desde a limpeza do templo, cantigos, reza até ao termino em que é servido um Inache para os presentes. (SILVA 2018)
} 
As entrevistas foram gravadas dentro das igrejinhas que recebem a celebração, no caso da Divindade do bairro Santa Rosa, segundo dona Maria Lucia, os primeiros donos do Divino Espirito Santo, vieram do estado de Minas Gerais, a imagem pertencia aos bisavós dos sogros de Dona Maria Lúcia. Ao chegar em Marabá, eles residiram primeiro em uma vila do município chamada Espirito Santo que, segundo a informante, era chamada de Vila do Cabeludo, o nome atual foi dado pelo então prefeito, Sérvulo Brito, devido a realização da festividade por seus sogros no local. Em seguida, as narrativas foram transcritas para que pudéssemos realizar a análise das falas.

2 Olha essa festividade, ela é a mais velha daqui de Marabá sabe?! Eu acho que até daqui da região mesmo dos município, porque ela era do sogro, dos avôs do meus sogro aí foi passando de geração pra geração, então nós já tamo entrando na quarta geração, então calculadamente dá um cento, um século e meio. (Informante 1)

A Divindade do bairro Santa Rita, conforme nos contou a senhora Marinalva Silva da Paz (informante 2), tem 110 anos de celebração e é originária da Vila Ponta de Pedra, pertencente ao munícipio de São João do Araguaia e foi confiada a ela por sua mãe, que já havia recebido a responsabilidade de seu avô e assim sucessivamente.

\footnotetext{
3 É porque assim, quando eu peguei eu já peguei da minha mãe, que ela já pegou do meu bisavô, então já vem de muito tempo que meu bisavô já pegou do avô dele, que ela contava pra nós, agora tá vindo de lá 'ra cá, aí agora ficou comigo né?! Agora daqui vai ter que um da família assumir quando eu partir, porque na verdade é a grande a responsabilidade né?! [Entrevistadora: Veio de onde?] da Ponta de Pedra, na realidade tem uns quinze anos que a gente tá aqui (...) já tem cem anos, um bocado de ano (Informante 2).
}

Trata-se de uma pesquisa qualitativa que valorizou o método abordado por William Labov, a narrativa de experiência pessoal, conforme nos aponta Tarallo (1997), como a melhor alternativa para o conhecimento e a elaboração de hipóteses satisfatórias para descrever e analisar a diversidade ou a variação linguística, que se sustenta pela coleta de dados linguísticos, obtidos por meio de narrativa de experiência pessoal, pois "Os estudos de narrativas de experiência pessoal têm demonstrado que, ao relatá-las, o informante está tão envolvido emocionalmente com o que relata que presta o mínimo de atenção ao como." (TARALLO, 1997, p. 22), possibilitando dessa maneira, ao pesquisador a situação ideal para a coleta de dados linguísticos que representam a fala espontânea do informante.

O método laboviano consiste na realização de entrevistas que estimulem o informante a narrar fatos sobre sua vida, o grupo que pertence ou sobre o local em que está inserido, de maneira espontânea. Vale ressaltar que o entrevistador faz a pergunta introdutória e interfere o mínimo possível durante a narração dos fatos. O pesquisador serve apenas como mediador e conduz a entrevista de acordo com o que deseja obter, mas sem um questionário escrito e pronto, pois assim o entrevistado se sentirá livre para falar sem se prender e obedecer às normas linguísticas ou rituais.

\section{Da organização do glossário}

O trabalho foi realizado a partir da coleta audiovisual de entrevistas com duas importantes donas de divindades da cidade de Marabá que residem nos bairros Santa Rosa e Santa Rita. Em seguida, as narrativas foram transcritas e os termos que identificam e nomeiam os personagens de cada festa foram selecionados, analisados, comparados e foram incorporados os possíveis conceitos para esses termos. Finalmente, documentamos uma das 
principais festividades da cidade que é a realizada no bairro Santa Rosa, por ter a tradição de 150 anos, desde a chegada dos primeiros donos da divindade oriundo do estado de Minas Gerais.

A organização do Glossário se deu a partir do levantamento das palavras e expressões usadas para descrever as diferentes personagens que participam da realização e que assumem um significado especifico para o ritual da festa.

A pesquisa está sendo executada aos poucos para a elaboração da dissertação de mestrado, então esse artigo é uma pequena amostra do trabalho final.

\subsection{Da macroestrutura}

A macroestrutura escolhida apresenta os verbetes em ordem alfabética organizados em um campo semântico apenas, no caso, personagens que compõem a festa, acompanhados das informações gramaticais, definições, contexto, notas e forma dicionarizada.

As definições apresentadas foram baseadas nas informações disponibilizadas pelas entrevistadas e foram transcritas no sistema computacional Lexique Pro, com as seguintes etiquetas: Lexema; Categoria gramatical; Definição, Contexto, Nota, Variante, Remissiva e Forma dicionarizada.

Constituem entradas ou lexemas os termos que denominam os personagens que fazem parte das duas Divindades pesquisadas para este artigo. É importante destacar que o glossário apresentará a grafia regular da ortografia da Língua Portuguesa, mesmo sendo o registro de língua falada de uma manifestação popular religiosa.

\subsection{Da microestrutura}

Os verbetes do Glossário estão organizados obedecendo a seguinte estrutura:

Termo-entrada + Categoria gramatical + Definição + Contexto + Nota + Forma dicionarizada, como no exemplo abaixo:

Alferes da Bandeira s.m. Pessoas responsáveis pela colocação da bandeira do Divino no mastro que é erguido no último sábado de celebração. "Eles são responsáveis pelo jantar, na noite deles, pela celebração e colocação da bandeira no mastro, no último sábado da festividade." < s.m.2n. antiga patente de oficial, logo abaixo de Tenente. (HOUAISS, p. 41).>

Utilizamos os seguintes sinais gráficos e abreviaturas para estruturar o glossário:

a) Referência gramaticais:

s.m. Substantivo masculino

s.f. Substantivo feminino

b) Sinais gráficos:

... interrupção da fala da entrevistada.

(...) indica trecho diferente da fala ou que a fala da informante não iniciou naquele trecho transcrito.

[ ] Fala do inquiridor.

" " Marca a fala do entrevistado.

$<>$ Indica a forma dicionarizada. 


\title{
5 Uma proposta de análise dos termos
}

A manifestação do Divino Espírito Santo inicia-se em Marabá no mês de maio, período em que se acredita ser a ascensão e batismo com Espírito Santo dos apóstolos, registrado na Bíblia Cristã e vai até meados de agosto.

Realizamos duas entrevistas com donas das divindades mais antigas do município, a pertencente a Dona Maria Lucia Gomes Dias (informante 1), que conta com 150 anos aproximadamente, no Bairro Santa Rosa e o da Dona Marinalva Silva da Paz (informante 2) que remonta um século de existência, celebrada atualmente no Bairro Santa Rita.

As duas entrevistadas relatam que muita coisa mudou na festa, pois a cidade cresceu, o tráfego de automóveis e a vida moderna das pessoas diminuíram a frequência nas rezas e alteraram o modelo do festejo que agora não realiza mais os giros, procissões a pé que os integrantes do Divino faziam de casa em casa para arrecadar donativos e realizar rezas nas casas dos promesseiros ou de qualquer pessoa que quisesse receber a imagem do Divino, a bandeira e seus integrantes para ter sua residência abençoada.Entretanto, como pontua Dona Marinalva da Paz, esse ritual não é mais possível,

\begin{abstract}
4. Porque nem todos (foliões) são de perto, muitos são de longe, aí a gente fica meu Deus será que a comida vai dar, aí tudo é uma preocupação pra gente, aí com a dificuldade, a crise que está hoje né, aí eu sou uma desemprega, aí a gente se preocupa assim, mais por essa parte. A festividade é de três dias, porque já veio de lá dos troncos velhos, sempre foi três dias, só que antes, só mudou uma coisa porque quando a gente morava lá na Ponta de Pedra, a minha mãe ela saia o giro né, uma semana porque sempre meu avô saia, aí as vezes a pessoa fazia promessa, aí ele tinha que ir pra aquela casa, as vezes para doar um almoço, uma janta, ai ele ia, então ficava assim tipo essa tradição de sair uma semana, toda vez ele ia, aí aqui a gente não, depois que a gente veio pra cá agente não fez isso. Porque aqui sabe esse pessoal, muitos critica muito, já tem muito crente, aí tem aquela diferença, aí a gente preferiu fazer mesmo só os três dias (Dona Marinalva da Paz, bairro Santa Rita).
\end{abstract}

A Divindade da informante 2 tem aproximadamente 100 anos de existência, sua dona afirma ter recebido de sua mãe Dona Maria do Socorro quando faleceu, que já havia recebido do seu bisavô que recebeu de seus pais. Aliás essa é uma característica da festividade, a responsabilidade, como elas dizem, é passada de geração para geração e não pode ser interrompida, elas não conseguem mensurar exatamente quando essa festividade iniciou em suas famílias, pois sempre existiu.

No caso da informante 2, a celebração surgiu na Vila Ponta de Pedra, no município de São João do Araguaia, que fica há 50km de Marabá, e sua família se mudou há dez anos para Marabá e desde então permanece com o festejo, mas com outra configuração como fica evidente em sua fala.

Ao ouvir novamente as entrevistas, coletamos os termos que nomeiam os personagens do Divino Espírito Santo nos dois bairros, foram identificados 14 vocábulos que nomeiam as figuram da Divindade, dentre elas:

$A-a$

Alferes da Bandeira s.m. Pessoas responsáveis pela colocação da bandeira do Divino no mastro que é erguido no último sábado de celebração. "Eles são responsáveis pelo jantar, na noite deles, pela celebração e colocação da bandeira no mastro, no último sábado da festividade." < s.m.2n. antiga patente de oficial, logo abaixo de Tenente. (HOUAISS, p. 41).>

Anjos S.m. Personagens angelicais representadas sempre por crianças e simbolizam a ascenção de Nossa Senhora. "Os anjos, a minha mãe dizia que quando a gente parte desse lado pra o outro é eles que levam a alma da gente pro... eles ficam do lado da Imperatriz" (Marinalva da Paz - Informante 2) < s.m. 1. REL mensageiro celestia entre Deus e os homens 3. p.ext.criança vestida de anjo em procissões e outras ceimonias católica.> 
Capitão do Mastro s.m. Pessoa responsável pelo ritual do levantamento do Mastro que acontece sempre às 17 horas do último sabado da Festa. "Responsável no sábado Capitão do Mastro falado e da bandeirinha que é colocada Alferes da Bandeira é um casalzinho, sempre mais é adulto, mas tem vez que é criança também. E eles também são responsável pelo jantar do sábado, da noite deles (...) responsável também pela celebração do terço que vai ser realizado." (Maria Lucia - Informante 1) < (ca-pi-tão) [.:ães; fem.:capitã e capitoa] MIL posto militar abaixo de major e acima de tenente 2 MIL oficial nesse posto 3 comandante de navio 4 p.ext.chefe de qualquer grupo. (HOUAISS, 2015, p. 179).>

$D-d$

Dono da Divindade S.m. Pessoa que tem a imagem do Divino Espirito Santo, que é representado pela imagem de uma pomba branca sempre em cima de uma coroa com fitas de diversas cores que representam os dosn do Espírito Santo. "Assim eu que sou dona da Divindade sou responsável pela organização da festa, comida, tudo e é muito gasto." (Marinalva da Paz - Informante 2) $<$ (di-vin-da-de) s.f.: 1 REL natureza ou condição daquele que é divino < ad. de Cristo 2 REL Deus, segundo o monoteísmo 3 REL nte ou ser divino, no politeísmo < Vênus era a d. do amor $>4$ p. ext. qualquer pessoa ou coisa que se venera.>

$F-f$

Foliões S.m. Pessoas responsáveis pela organização da reza, da festa e das cantorias no domingo de enecerramento do festejo, ponto alto da celebração, em que ocorre a mesa do Imperador. "Tem Foliões né?! pra completar mesmo são 12 foliões, mas raramente a gente encontra, porque assim eu sou rígida e eles gostam muito fora, particular da bebida e eu não aceito sabe, aí as vezes eu fico com seis, completa mais com uns noitários antigos pra fazer a mesa né?! (Entrevistadora: Por que 12? O que eles fazem?) simbolizam os 12 apóstolo de Jesus (...) a função deles tem os instrumentos que eles tocam, cantam, versos que eles cantam lindo demais, na hora da coroação são eles que fazem a coroação do Imperador com a imagem, da Imperatriz também são eles que fazem né?! São eles que põe todo aquele respeito no momento da oração, do almoço... pra não virar bagunça." < (fo-li-ão) [pl.: -ões; fem.: foliona] adj. s.m. 1 que $(\mathrm{m})$ brinca carnaval 2 p.ext que $(\mathrm{m})$ gosta de festas.> (HOUAISS, p. 462).

I - i

Imperador s.m. Figura mais importante no Festejo do Divino Espírito Santo, é a representação da Família Imperial no Brasil. "Acontece às $11 \mathrm{~h} 30$ a coroação do Imperador, a gente sai em procissão pra pegar o Imperador na casa onde ele vai ficar, lá depois dele eles saem em procissão pra pegar a Imperatriz, ai de lá a gente vem procissão cantando até chegar aqui, chegando aqui logo tem a coroação dele, aí ele se preparando pra na hora da mesa, ele que vai coroar todos os noitários ali." < (im-pe-ra-dor) [pl; -es] s.m. monarca supremo de um império.> (HOUAISS, p.524).

Imperatriz s.f. Figura mais importante no Festejo do Divino Espírito Santo, é a representação da Família Imperial no Brasil. " (...) lá onde a gente pega a Imperatriz a gente coroa ela, aí só o Imperador a gente coroa aqui no pé do altar. (Marinalva da Paz - Informante 2) < (im-pe-a-triz) [pl. -es]s.f 1 mulher que govern um império 2 esposa do imperador. > (HOUAISS, p. 524).

$J-j$

Juiz S.m. Pessoa que organiza a Mesa do Imperador para o almoço, direcionando a reza e o comportamento das pessoas. "O juiz e a juiza dá juizo pra quem não tem, risos." < (juiz) [pl..: -es; fem.: juíza] s.m. 1 DIR quem tem autoridade pública e poder para julgar, na qualidade de administrador da Justiça do Estado 2 p.ext. quem tem poder de julgar < foi j. em um concurso de beleza $>$ 3 p.ext. ESP. quem é encarregado de constatar faltas e aplicar o regulamento de um jogo esportivo; árbitro.> (HOUAISS, p. 569).

Juiza S.f. Pessoa que organiza a Mesa do Imperador para o almoço, direcionando a reza e o comportamento das pessoas. "O juiz e a juiza dá juizo pra quem não tem, risos." < não dicionarizado.>

$N-n$

Noitários s.m. Pessoas responsáveis pela organização das novenas, desde a limpeza do templo, cantigos, reza até ao termino em que é servido um Inache para os presentes. " Não sabe, agora que não estão fazendo muito, mas por exemplo, ele era responsável por tudo, pela limpeza do salão, decoração do altar sabe? Aí lanche fica a critério dele, fica a critério deles, né, servir um lanche após a celebração do terço." < não dicionarizado.>

$P-p$ 
Par da Salva s.m. Uma espécie de soldado, guardião do Imperador que é a figura máxima da festividade. O pardassalva protege o Imperador, tanto fisicamente como espiritualmente. "Ele é dois anos Pardassalva que é guardiã do Imperador, na época eles falavam soldadinho do Imperador, mas são guardião do Imperador." < não dicioarizado.>

Promesseiros s.m. Nomeia as pessoas que pagam promessas ao Divino Espírito Santo, pois tiveram bençãos alcançadas. "[Anjos são só meninas?] Só meninas, tem deles que aparecem Promesseiros né?! Homenzinhos. (Informante 1) < não dicionarizado.>

$R-r$

Rosas S.f. Figuras representadas por três meninas que acompanham a Imperatriz. "São três garotas com as cores da coroa do Divino né, que a gente dá o nome Rosas, aí essas Rosa já segura a vaga delas pra chegar a Imperatriz do Divino." (Informante 1) < (ro-sa) s.f. BOT 1 a flor da roseira.> (HOUAISS, p. 835).

$S-S$

São Miguel s.m. Representação do Arcanjo que traz consigo uma balança para pesar as almas, que participam da Festividade. "Aí tem o São Miguel que ele vai pesar essas almas todinhas também, tem um garotinho né?! com a balancinha de São Miguel, mas agora está um problema sério que eles não querem usar saia, porque tem uma saietinha né?! São Miguel e eles não querem. " (Informante 1) < não dicionarizado.> 
É importante frisar que a festa é estruturada com figuras que remontam o Império brasileiro, traz presente em sua organização personagens da realeza, uma vez que a festa foi realizada pela primeira vez por membros da realeza portuguesa, como mencionamos em outro tópico.

Outros termos como Juiz e Juíza aparecem apenas no festejo do Bairro Santa Rita e são responsáveis pela organização da celebração no último dia da festa, são eles quem monitoram o comportamento dos foliões durante a mesa do Imperador, que é preparada pelos foliões, para o almoço de domingo, momento alto da festa em que o Imperador e a Imperatriz são coroados com a imagem do Divino Espirito Santo.

Outra característica importante, são os critérios usados para a escolha da Imperatriz e do Imperador que, no caso do Bairro Santa Rosa, os jovens precisam passar por algumas etapas, como Rosas no caso das meninas, Par da Salvas no caso dos meninos e Anjos para os dois. Dona Maria Lúcia afirma ser muito rigorosa com essa preparação, pois "a Divindade precisa ser respeitada".

Já no caso do Bairro Santa Rita, o critério usado por Dona Marinalva é especificamente no caso das meninas que não podem estar gravidas e devem ser menores de 18 anos, assim como os meninos que será a ilustre figura, pois segunda a mesma, ainda são puros.

\footnotetext{
5.Tem toda uma preparação pra eles, eles são coroados com o Divino, o Imperador é coroado com o símbolo do Divino pra depois ele coroar todos os noitários, no grande dia né tem a coroação dele e tem a coroação dela também (Dona Maria Lúcia - Informante 2).
}

Outras personagens que merecem destaque são os Anjos que, nas duas festividades, são crianças, no entanto a informante 1 afirmou que em sua festividade são apenas meninas que já guardam seus lugares para serem Rosas e depois Imperatriz; apenas de vez em quando é que aparecem promesseiros que colocam seus filhos como Anjos, mas sempre serão meninas, ao contrário da informante 2 que afirma serem meninos e meninas.

As entrevistadas acreditam que os Anjos devem ser crianças pequenas, pois são criaturas puras e que ficam sempre protegendo e guiando as almas que deixam o plano físico. Além desses, temos a figura de São Miguel que, com uma balança, mede o peso das almas e seus erros, como coloca Dona Maria Lucia.

Verificamos que alguns dos termos usados para nomear os personagens não estão 
dicionarizados, a exemplo de Promesseiros, Par da Salva, Noitários; esses vocábulos são usados especificamente para a festividade e não são encontrados em outras festividades da Igreja Católica.

Todos os termos são classificados morfologicamente como substantivos, pois nomeiam os personagens que estruturam a festa e pertencem a um campo semântico. Termos como promesseiros e noitários são derivados por sufixação, a derivação consiste em formar uma palavra nova (derivada), a partir de outra já existente (primitiva). Realiza-se de quatro maneiras: por sufixação; por prefixação; por derivação parassintética e por derivação regressiva. (CEGALLA, 2008, p. 96). Os vocábulos citados surgem respectivamente de promessa e noite, acrescidos de um sufixo, que dão origem aos novos termos em questão.

Já Par da Salva, Capitão do Mastro, Dono da Divindade, Alferes da Bandeira e São Miguel são termos formados pelo processo de composição por justaposição, em que "associamse duas ou mais palavras ou dois ou mais radicais para formar uma palavra nova. A composição pode efetuar-se por justaposição unindo-se duas ou mis palavras (ou radicais) sem lhes alterar a estrutura." (CEGALLA, 2008, p. 96).

Além disso, são sintagmas nominais que servem para delimitar, definir o personagem, por exemplo, Capitão do Mastro, encontramos o termo Capitão dicionarizado que para Houaiss (2015, p. 179) significa "posto militar abaixo de major e acima de tenente", no contexto da festividade capitão acrescido da locução "do mastro", ganha um novo significado e importância, quem cuida, protege e ergue o mastro, símbolo da festividade que serve para identificar para os transeuntes que naquele local o Divino está presente.

\section{Considerações finais}

As festas do Divino Espírito Santo em Marabá, especialmente as que conseguimos registrar, são carregadas de simbolismo e representações que remontam a nobreza brasileira do período imperial.

Os verbetes apresentados representam um recorte da nossa pesquisa para a elaboração da dissertação de mestrado em Linguística em que pretendemos apresentar o glossário da festa do Divino em Marabá, fundamentado na Terminologia, estudo das línguas de especialidade, como menciona Alves (1998), e na Socioterminologia, evidenciando a relação que a terminologia estabelece com a sociolinguística.

Faulstich (1995) apresenta como auxiliares da pesquisa socioterminológica os 
princípios da sociolinguística, dentre os quais enfatiza os critérios de variação e de perspectiva de mudança além dos princípios da etnografia.

Buscou-se levar em conta as variações dos modos de designar cada personagem da festividade nos diferentes espaços geográficos em que ocorrem as respectivas festas: bairros Santa Rosa e Santa Rita. O propósito é evidenciar não apenas a definição e o contexto da figura representada, mas também a variação dos sujeitos em determinadas funções, ora exercidas por indivíduos de gêneros diferentes e até por mais de uma pessoa, dependendo do local da celebração. A exemplo, notou-se que, na figura do Alferes da bandeira, segundo a Informante 1 , é um casal e, para a informante 2, é representado por uma mulher.

Percebemos durante as entrevistas que as duas mulheres envolvidas e donas do Divino estão ligadas não apenas pelo sentimento religioso à festividade, mas também pelo apelo sentimental e pela tradição da família; sentem-se responsáveis pela perpetuação da tradição que pertence às famílias há mais de um século.

Apesar das dificuldades que as duas dizem passar para organizar e manter sozinhas todos os custos da festa, desde passagens para os foliões até alimentação, remédios, elas não desistem, pois a fé no Divino e em suas obrigações para com os antepassados são fatores determinantes para a manutenção de uma tradição tão rica e diversa.

\section{REFERÊNCIAS}

ALVES, I. M. Questões epistemológicas e metodológicas em terminologia. In: CARVALHO, N. M. de; SILVA, M. E. B. (Orgs.) Lexicologia, lexicografia e terminologia: questões conexas. Encontro Nacional do GT de Lexicologia, Lexicografia e Terminologia da ANPOLL, I. Anais. Recife: UFPE, 1998.

ABREU, Martha, O Império do Divino: festas religiosas e cultura popular no Rio de Janeiro, 1830 - 1990. ed. Nova Fronteira; São Paulo: Fapesp, 1999.

BAKHTIN, Mikhail Mikhailovitch, 1898-1975 - A cultura popular na Idade Média e no Renascimento: O contexto de François Rabelais / Brasília: Editora da Universidade de Brasília 1993.

BIDERMAN, M.T.C. As ciências do léxico. In: OLIVEIRA, A.M.P.P de ISQUERDO, A. N. (Orgs). As ciências do Léxico: Lexicologia, lexicografia, terminologia. $2^{a}$ ed. Campo Grande: Editora UFMS, 2001, p. 13-22.

BRANDÃO, Helena H. Nagamine, Introdução à analise do discurso. ${ }^{a}$ ed. - Campinas, SP: Editora da Unicamp, 2002.

CÂMARA Jr. J. Mattoso. Dicionário de filologia e gramática. 4ª ed. Rio de Janeiro: J. Ozon, [s/d].

CEGAllA, Domingos Paschoal. Novíssima Gramática da Língua Portuguesa. 48. Ed. rev. São Paulo: Companhia Editora Nacional, 2008.

CONRAD, R. Tumbeiros: o tráfico de escravos para o Brasil, Trad. São Paulo, Brasilense, 1985. 
DA MATTA, Roberto. Carnavais Malandros e Heróis: para uma socialização do dilema brasileiro. $6^{\mathrm{a}}$ ed. Rio de Janeiro, Rocco, 1997.

CABRÉ CASTELLVI, M. T. La terminologia:. teoria, metodologia, aplicaciones. Barcelona, Antártida, 1993. FISHMAN, J. A. A sociologia da linguagem. In. Sociolinguística [Fonseca, Maria Stella V. e Neves, Moema F. (orgs)], Rio de Janeiro, Eldorado, 1974.

FAULSTICH, E. Socioterminologia: mais que um método de pesquisa, uma disciplina. Ciência da Informação, v. 24, n. 3, 1995.

FAULSTICH, E. "A função social da terminologia", Humanitas, São Paulo, FFLCH, USP, pp. 167-183, 1999. Proposta metodológica para a elaboração de léxicos, dicionários e glossários. Brasília: 2001. LIV/UnB/ Centro LexTerm, 2001.

GAUDIN, François. Socioterminologia: um itinerário bem-sucedido. In: ISQUERDO, A. N.; DAL CORNO,

G. O.M. (Orgs.) As ciências do léxico: lexicologia, lexicografia e terminologia, volume VII, 2014, p.293309.

HOUAISS, Antônio; VILLAR, Mauro de Salles. Dicionário Houaiss da língua portuguesa. São Paulo: Moderna, 2015.

VASCONCELOS, A. Glossário da terminologia do caranguejo: uma perspectiva socioterminológica. In RAZKY, A. (Org.) Estudos geo-sociolinguísticos no estado do Pará. Belém, 2003, p. 143-154. 